\title{
Uncovering the Power of Natural Endorsements: A Comparison With Celebrity-Endorsed Advertising and Product Placements
}

\begin{abstract}
Despite the vast literature on celebrity endorsements in advertising, research to date has not assessed whether and how celebrity-brand associations created via traditional endorsements or product placements compare to more natural associations that emerge from real-life celebrity images through social media. This experiment systematically compares the impact of different brand-celebrity associations on consumer perceptions of the celebrity's credibility and their responses to a new brand associated with that celebrity. The results reveal that, unlike more commercial brand associations, natural brand-celebrity associations can yield strong brand effects without eroding the celebrity's credibility. The findings are especially insightful given increasing numbers of natural brand-celebrity associations in social media.
\end{abstract}

Keywords: product placement; advertising; celebrity endorsement; brand impact; human brand; persuasion; credibility 


\section{Introduction}

Many studies have examined consumers' responses to celebrity endorsements in advertising (Amos, Holmes, and Strutton 2008; Bergkvist and Zhou 2016; Choi, Lee, and Kim 2005; Choi and Rifon 2012; Kamins et al. 1989; Silvera and Benedikte 2004). Throughout the consumer and advertising literature, celebrities are treated as signals that, when tied to a brand, influence advertising awareness and brand image (Bergkvist, Hjalmarson, and Mägi 2016; Hung 2014; Kamen, Azhari, and Kragh 1975; Till and Shimp 1998), and ultimately consumers’ purchase intentions (Bush, Martin, and Bush 2004; Ohanian 1991). Findings show that celebrities create a positive attitude towards the brand (Kamins et al. 1989) and a distinct meaning for the endorsed brand (McCracken 1989). Ultimately, celebrity endorsements are believed to generate a greater likelihood of customers' valuing and choosing the endorsed brand (Hackley and Hackley 2015; Heath, McCarthy, and Mothersbaugh 1994; Kahle and Homer 1985).

Not surprisingly, most research related to celebrity-brand associations has been conducted within traditional advertising contexts, in which a celebrity explicitly endorses a brand. Yet, associations between celebrities and brands may be formed outside the traditional endorsement process. Advertisers, well aware that paid celebrity endorsements may trigger negative cognitive responses and thus impair consumers’ persuasion (Moore, Mowen, and Reardon 1994, Friestadt and Wright 1994), have thought up new forms of endorsement. This is especially notable with product placement, the practice of integrating brands within the content of entertainment programs instead of promoting the brand during the advertising breaks (Russell 2002). Through the practice of product placement, celebrities are associated with brands but in an implicit endorsement embedded in the entertainment context (Balasubramanian 1994). With the rise of social media, celebrities’ private lives are increasingly visible to the public, providing consumers with information about brands they 
might consume or use in their real lives (Jin and Phua 2014). These publicly visible displays of consumption potentially generate endorsement-like effects on how consumers view brands associated with celebrities. Yet, research to date has not assessed the differences between such natural endorsements and more commercialized ones.

The purpose of this study is to systematically compare the effectiveness of three types of celebrity-brand associations: traditional advertising endorsement, where a brand and a celebrity are linked as part of a commercial advertisement; product placement, where the brand and the celebrity are linked through the content of an entertainment product; and reallife displays, where the brand and the celebrity are linked through normal life happenings. An experiment is conducted that manipulates the type of celebrity-brand endorsement and examines the resulting perceptions of the celebrity and the impact of the celebrity on several key consumer responses to the brand. In order to assess the relative impacts of different types of endorsements, the conditions are compared not only amongst themselves but also against a control condition in which no celebrity-brand association exists.

\section{Theoretical Framework}

\section{Celebrity-Brand Associations}

The use of celebrities as advertising endorsers and agents of persuasion can be traced back to the late nineteenth century (Erdogan 1999). Advertisers have long capitalized on the idealized images associated with celebrity lifestyles and entertainment content (Hirschman and Thompson 1997) to link their brands to celebrities via traditional endorsements. The advertising practice is based on the assumption that audiences envy, admire, and wish to emulate the consumption constellations and aspirational lifestyles that surround celebrities (Festinger 1954; Hirschman and Thompson 1997). The prevalence of celebrity endorsement in advertising differs across countries. While Japan and Korea feature celebrities in over $40 \%$ 
of their TV ads, it amounts to 12\% in the UK, and 10\% in the U.S. (Millward Brown 2013). Belch and Belch (2013) also found that 10\% of U.S. magazine ads in 2007 used celebrities. Reliance on celebrity endorsement also varies by product category, being more prevalent in the apparel category (32\% of total U.S. ads) than in the personal care category (14\%) and household products (4\%; Millward Brown 2013).

However, celebrity-brand associations may form in other ways than the ones commonly highlighted in the endorsement literature. The explosion of product placement in particular has led to associations between celebrities as characters in a movie or TV series and the brands that appear in the content of the entertainment vehicle (Russell 2002). In fact, the growth of product placements has significantly outpaced traditional advertising and product placement is now considered a 'strategic must-have' in marketers' toolkits (PQ Media 2016).

And finally, celebrities have increasingly strong social media presences and followings that give them direct contact with their large fan bases via their personal Instagram or Twitter accounts and Facebook pages. Selena Gomez, for example, has nearly 90 million followers on Instagram alone, amounting to potential views from almost 200 million accounts when adding Facebook and Twitter to the mix. Social media allows celebrities to provide information about themselves and their lives directly to consumers and this often includes other brands (Stever and Lawson 2013; Jin and Phua 2014). The rise in social media platforms further fuels a semblance of interactive relationship and closeness, as audiences can communicate directly (or seemingly so) with celebrities. Such relationships are prone to establish trust, a central tenet of credibility models, as well as perceptions of similarity. Indeed, people often assume that their television "friends" are like them, sharing similar beliefs and attitudes, even when this is inaccurate (Huckfeldt and Sprague 1995; Jussim and Osgood 1989). Advertisers and celebrities alike have realized the commercial potential of these more implicit forms of celebrity-brand associations. For instance, Selena Gomez has recently posted pictures of 
herself with Coca-Cola, Pantene, or Louis Vuitton products on Twitter. She reportedly charges up to $\$ 550,000$ per social media post (Heine 2016).

Given the increased advertising saturation and ever-rising presence of product placements across entertainment contexts, the audience may be increasingly skeptical about the more commercial brand-celebrity messages and these more natural 'real-life' associations may thus be more beneficial to brands.

\section{Impact of Celebrity-Brand Associations on Consumers}

Previous research on celebrity endorsements has adopted a persuasion focus and investigated the impact of a celebrity on attitude toward the endorsed brand (Bergkvist, Hjalmarson, and Mägi 2016; Eisend and Langner 2010; Kamen et al. 1975; Kamins et al. 1989), the development of brand meaning (McCracken 1989), and purchase intentions (Bush, Martin, and Bush 2004; Ohanian 1991). According to McCracken’s meaning transfer model (1989), brands gain meaning from their association with elements of popular culture, in particular celebrities, and consumers in turn adopt this meaning (McCracken 1989). This transfer process is especially likely when the celebrity is perceived to be knowledgeable about the brand s/he is associated with and thus have credibility in the eyes of the consumer (Misra and Beatty 1990; Russell and Stern 2006).

Although mere attitude toward the celebrity may directly transfer to the brand associated with the celebrity via an endorsement, it is also important that the audience feel that the celebrity endorsing the brand genuinely likes the brand (Silvera and Benedikte 2004). Consumers' brand evaluations are more positive when a celebrity endorser is perceived as motivated by product quality than as solely financially motivated (Bergkvist, Hjalmarson, and Mägi 2016). The persuasiveness of a message’s source thus depends on the audience's trust in 
the communicator and related perceptions of the communicator's credibility on the topic at hand (Hovland, Janis, and Kelley 1953; Amos et al. 2008). Previous research defines source credibility "as a communicator's positive characteristics that affect the receiver's acceptance of a message" (Ohanian 1990, 41) composed of three constituents, namely trustworthiness, attractiveness (Baker and Churchill 1977; Chaiken 1979; Kahle and Homer 1985), and perceived expertise (Ohanian 1991). These three characteristics drive the impact of celebrities on the endorsed brands (Amos et al. 2008). Introducing a time perspective to celebrity endorsement effects in advertising, Eisend and Langner (2010) found that, whereas attractiveness has an immediate impact, expertise has a more delayed one.

But perceived credibility is malleable. Indeed, previous research signals that a celebrity’s association with a brand may affect consumers' perceptions of the celebrity itself. Celebrities are sometimes referred to as human brands (Thomson 2006) and the meanings they convey are malleable and subject to change. McCracken's (1986) meaning transfer model conceptualized meaning as continually moving between brands, celebrities and consumers. Therefore, instead of a unidirectional flow of meaning or association transfers, it is conceivable that perceptions of the celebrities themselves change as a function of their associations with brands. The 2004 Jamie Oliver-Sainsbury's Supermarkets Ltd collaboration is a great illustration of this bidirectional meaning transfer: Halonen-Knight and Hurmerinta (2010) analyzed newspaper articles relating a controversy linked to Sainsbury’s advertising campaign where Jamie Oliver endorsed farmed salmon and at the same time refused to serve farmed salmon in his own restaurant. They found that although Sainsbury's actions were the original source of the negative publicity, the actual negativity in the media was associated with the celebrity (Jamie Oliver) and not the endorsed brand. More generally, Tripp, Jensen and Carlson (1994) found that consumers' perceptions of endorser credibility and likability lessen as the 
number of products a celebrity endorses increases. Clearly, consumers' responses to celebrities can also be affected by their associations with brands.

\section{Theoretical Predictions}

This research assesses whether the ways in which a brand is featured in the celebrity world affect consumers' responses to the brand and responses to the celebrity. On the brand side we measure attitude towards the brand, purchase intentions and willingness to pay as well as self-brand connection, a deeper relational construct that captures a brand's perceived closeness to one's self-concept (Escalas 2004). On the celebrity side, we measure how the different forms of endorsement may affect traditional measures of credibility, such as attractiveness, expertise and trustworthiness. As discussed above, the research accounts for the fluidity of celebrity perceptions and for the potential that perceptions of celebrity credibility vary as a function of the celebrity's endorsement of brands.

Based on the extant research on persuasion knowledge activation that results from knowing that a message is designed to persuade (Campbell and Kirmani 2000), "real-life" natural endorsements, which have more verisimilitude and appear more authentic, should trigger more positive outcomes, both on the celebrity side and on the brand side, than product placement or ad endorsement, both considered marketing forms of endorsement (Jin and Phua 2014).

H1: Consumers will perceive a celebrity as more credible following exposure to a real-life, natural association than following exposure to a commercial endorsement (product placement or advertising).

In turn, we hypothesize that natural brand-celebrity associations should lead to more positive brand-related responses than commercial forms of endorsements.

H2: Consumers' brand responses, namely brand attitudes (H2a), purchase intentions (H2b), willingness to pay (H2c) and self-connections to brand (H2d) will be more positive following 
exposure to a real-life, natural association than following exposure to a celebrity's commercial endorsement (product placement or advertising).

The driving force of the celebrity-brand process is that the stronger perceptions of celebrity credibility increase brand effects. Therefore, conditions that produce greater perceptions of credibility should also produce more positive responses to the brand associated with the celebrity. In other words,

H3: Celebrity credibility mediates the relationship between types of endorsement conditions and brand responses, namely brand attitudes (H3a), purchase intentions (H3b), willingness to pay (H3c) and self-connections to brand (H3d).

Although we expect this mediating process to explain all types of endorsement conditions, it should be especially strong in conditions where the association between the celebrity and the brand is greatest and most authentic (real-life association).

\section{Methodology}

An experiment was conducted to test the predictions. Different celebrity-brand associations were created and used in a between-subjects experiment to examine the differential impacts of commercial forms of endorsement (advertising and product placement) and more natural forms of endorsements on consumer responses to both the celebrity and the brand. The brand used was a real but unfamiliar brand, thus free of existing associations and attitudes, and the celebrity was a familiar, existing one, to assess variations in celebrity perceptions as a function of the conditions. Planned contrasts were used to compare the relative impacts of different types of celebrity-brand associations across conditions. A control condition in which no celebrity-brand association existed was also created as a baseline.

\section{Participants}


Participants were undergraduate students, members of the marketing department subject pool at a large Southwestern university in the United States. A total of 143 students ( 71 females) participated in the experiment for course credit. The study was administered on computers at individual workstations and at a self-paced rhythm. The questionnaire was divided into sections so that the participants could not see forthcoming information or alter their answers to previous questions.

\section{Selection of Stimuli}

Given the age of the participants (median age 20), energy drinks were selected for the study as a product category relevant to this segment, as in previous experimental research (Dahlén 2005; Russell and Russell 2010). At the time of the study, the brand V was available in the New Zealand and Australian markets but not in the United States where the research was conducted. Therefore, using materials featuring this brand allowed an externally valid context but maximized internal validity, as the brand was introduced as a new one in this market and therefore did not carry any previous associations.

Sarah Jessica Parker (SJP) was selected as the celebrity associated with the V brand. The American actress is best known for her role in the TV series Sex and the City and her primary audience is the 18-34 age group with a high Q score of $90 \%$ familiarity within this age group (Women’s Wear Daily, 22 March 2007, 14). At the time of the study, the TV series had concluded but was showing on prime-time network television, and a potential Sex and the City movie was due to be released a few months later. A pretest amongst a group similar to that used in the main study for this research (university students) confirmed that all were familiar with the celebrity, and that her image was easily and readily recognizable.

SJP was also a good candidate for the study because of her existing associations with brands in multiple forms: she has served as an official celebrity endorser in marketing 
communications campaigns for fashion and beauty brands, but not for energy drinks; her entertainment content presence is often surrounded by brand placements; and she is often seen in magazines and on social media, caught in real life by her fans or by journalists (Bullen 2009). The brand-celebrity association was expected to be generally more congruent than incongruent (Misra and Beatty 1990).

\section{Experimental Manipulations}

Participants were randomly assigned to one of four conditions. After a brief introduction to the study and completion of the Institutional Review Board requirements for informed consent, the participants were presented with the experimental manipulations. In the three 'experimental' conditions, participants were exposed to three photos; two of them were the same in each condition, and the last one had been digitally altered to seamlessly show Sarah Jessica Parker holding a bottle of the V energy drink. The photos were presented as either "taken by passers-by who spotted SJP on the streets of New York” (real-life condition), “taken from SJP's Sex and the City: the Movie to be released at the end of May and that was shot mainly in New York" (product placement condition), or "from a forthcoming commercial for a new energy drink called "V" showing SJP in the streets of New York" (ad endorsement condition). Appendix 1 shows the composition structure of each of the visual stimuli per experimental condition.

In all three conditions, participants were asked to take a few minutes to observe the photos. Cognitive responses were elicited in the three experimental conditions using the wellaccepted thought-listing procedure (Greenwald 1968; Wright 1973). Participants could list up to 10 "thoughts (they) had while (they) were looking through the photos.” These responses were used to identify any participant who may be suspicious of the manipulation and these were filtered out. 
The control condition contained no photos of SJP but only presented the bottle of $\mathrm{V}$ and the statement ' $\mathrm{V}$ provides people who lead a busy lifestyle with a boost of energy and vitamins in one (non-alcoholic) drink. V will soon be available in (state) and we would like to know your opinion about it.” This control condition was important to gather baseline reactions to the V brand as well as to obtain baseline reactions to the celebrity Sarah Jessica Parker without any connection to the brand.

\section{Brand Measures}

Following the thought-listing task, participants were told that they "may have noticed that, on two of the photos, SJP was holding a bottle of $\mathrm{V}$ and that $\mathrm{V}$ is a new energy drink brand currently only available in New York but that will soon be available nationwide.” In the control condition, the same information about $\mathrm{V}$ was provided without reference to the photos or SJP. All remaining questions were the same in each condition. Participants were asked if they had heard of the $\mathrm{V}$ brand before. They were then informed that "V provides people who lead a busy lifestyle with a boost of energy and vitamins in one non-alcoholic drink" and that "it will soon be available in (state where the study was run) and we would like to know (their) opinions about it."

Attitude toward the V brand was assessed on a six-item, five-point semantic differential scale (negative - positive, unfavorable - favorable, strongly dislike - strongly like, bad - good, low quality - high quality, uncool - cool; $\alpha=.94)$. Purchase intention was assessed with two Likert-like scale items (I look forward to V being available in (state); I would definitely like to try $\mathrm{V} ; r=.71$ ) anchored by strongly disagree (1) and strongly agree (5). Finally, self-brand connection, which captures the degree to which consumers feel that a brand is closely associated to their self-concept (Escalas 2004), was measured on a three-item, 5-point scale (V seems like my kind of brand; V seems like a brand I can see myself drinking; 
V seems to reflect who I am; $\alpha=.91)$. The order of all these brand measures was randomized to ensure that there were no order effects. Participants were then asked to indicate how much they would be willing to pay for a 20-ounce bottle of $\mathrm{V}$, using a drop-down menu in 5-cent increments. Willingness to pay is a key, reliable and externally valid indicator of the overall value of a brand to consumers (Le Gall-Ely 2009; Miller et al. 2011).

\section{Celebrity Measures}

The questionnaire's focus then turned to the celebrity. Participants in the control condition read a brief introduction to this section given that it dealt with a celebrity that they had not seen in the previous section. Three dimensions of celebrity credibility were measured: perceived attractiveness (attractive, good looking, sexy; $\alpha=.96$ ), trustworthiness (honest, sincere, trustworthy; $\alpha=.89$ ), and expertise (knowledgeable, experienced, expert; $\alpha=.82$ ). All were Likert-like scales anchored by strongly disagree (1) and strongly agree (5) (Ohanian 1990; Amos et al. 2008).

Familiarity with the celebrity was assessed on a three-item scale (I am very familiar with her, I feel like I really know her, I feel like I know a lot about her; $\alpha=.81$ ). Attitude toward the celebrity was measured with three items (I really like her; I am a big fan of hers; She is someone I would like to know in person; $\alpha=.89$ ). All scale items were anchored by strongly disagree (1) and strongly agree (5). Again, the order of all measures in this section was randomized to ensure that there were no order effects.

\section{Product Category Involvement}

Because involvement is an important factor of attitudes and message effectiveness (e.g., Gill, Grossbart, and Laczniak 1988; Greenwald and Leavitt 1984), a baseline measure of product category involvement was collected before the experimental manipulations, using a 
three-item five-point semantic differential scale (To me, energy drinks are: bad - good; To me, energy drinks are: unnecessary - necessary; To me, energy drinks are: unimportant important; $\alpha=.89)$.

Upon concluding the experiment, and after an unrelated 15-minute distracter task, participants were asked to "name the new energy drink used in the first phase of this study." Then, as a manipulation check. they were asked to select one of four options regarding how this new drink was promoted: 1) photos of SJP in a forthcoming commercial, 2) shots of SJP's forthcoming movie, 3) photos of SJP in real life and 4) no reference to photos. Finally, demographic information was collected.

\section{Results}

\section{Background Information}

Only one participant had heard of the $\mathrm{V}$ brand before. A conservative filtering process was used to check demand effects and 12 participants were removed from analysis because their thought-listing answers indicated that they noticed that the photos may have been altered or because they were skeptical about the experiment.

\section{Manipulation Checks}

All manipulations worked appropriately as, upon concluding the study, participants correctly identified the way the brand was promoted in the early parts of the experiment by specifically indicating that it had been promoted with photos of SJP in real life in the real-life condition (26 out of 27), shots of her forthcoming movie (27 out of 33), photos of a forthcoming commercial in the ad endorsement condition (24 out of 34), and, in the control condition, that it simply featured the V bottle image without any celebrity photos (26 out of 38). 


\section{Differences in Perceptions of Celebrity Credibility}

All means are reported in Table 1. An ANOVA comparing celebrity’s perceived credibility across the four experimental conditions revealed a marginally significant effect of the endorsement conditions $(F(3,130)=2.55, p=.06)$. Planned contrasts further show that, as predicted by H1, overall credibility is significantly higher in the real-life condition than in the product placement condition $(t(130)=-2.75, p=.01)$. A more precise exploration of the three key dimensions of celebrity credibility (expertise, attractiveness, and trustworthiness) using ANOVAs revealed a significant effect of the endorsement conditions for attractiveness only $(F(3,130)=2.86, p=.04)$. Planned contrasts show that attractiveness is significantly higher in the real-life condition than in the product placement condition $(t(130)=-2.79, p=.01)$ and in the ad endorsement condition $(t(130)=-2.15 ; p=.04)$. Although the ANOVA for expertise and trustworthiness did not yield an overall significant effect of the endorsement conditions (expertise: $F(3,130)=1.84, p=.14$; trustworthiness: $F(3,130)=2.21, p=.09)$, planned contrasts show significant differences between the real-life and product placement conditions. More specifically, the real-life condition leads to higher perceived expertise $(t(130)=-2.22 ; p$ $=.03)$ and higher perceived trustworthiness $(t(130)=-2.19 ; p=.03)$ than the product placement condition (means in Table 1).

This pattern supports H1: a real-life celebrity-brand association alters perceptions of the celebrity's credibility in a positive way. The celebrity is perceived as more credible than if associated with more commercial forms of endorsements, especially product placement. The latter leads to lesser perceived attractiveness. Clearly, as posited in H1, commercial forms of endorsements can be detrimental to the credibility of a human brand. By contrast, natural brand associations can increase trustworthiness as well as expertise.

\section{Differences in Responses to the Brand}


The analyses of brand responses controlled for product category involvement. Independence from the treatment variable has been checked, as an ANOVA showed no significant effect of the endorsement conditions on the level of involvement with energy drinks $(F(3,132)=.09, p=.96)$. See means for this control variable in Table 1 . Involvement with energy drinks is, as expected, significantly and positively correlated with all brand measures: brand attitudes $(r=.32, p=.000)$, purchase intentions $(r=.40, p=.000)$, willingness to pay $(r=.31, p=.000)$, and self-brand connections $(r=.41, p=.000)$.

To test H2, responses to the brand (brand attitude, self-brand connection, purchase intention and willingness to pay) were compared in a MANCOVA with the experimental condition as a between-subjects factor and the product category involvement as a covariate. The multivariate test reveals a significant main effect of condition on three of the brand responses: brand attitude $(F(3,130)=3.54, p=.02)$, purchase likelihood $(F(3,130)=2.78, p$ $=.04)$, and willingness to pay $(F(3,130)=2.60, p=.05)$. The effect of condition on self-brand connection is marginal $(F(3,130)=2.42, p=.07)$. Pairwise comparisons reveal that all four brand measures are significantly higher in the real-life condition compared to the control condition (brand attitude: $p<.01$; willingness to pay: $p=.01$; purchase likelihood: $p<.01$; self-brand connection: $p<.01$ ). We also observe that the real-life condition yields significantly higher willingness to pay than advertising endorsement $(p=.04)$ : from an ecological validity standpoint, the difference of $\$ .50$ in perceived value of the new $\mathrm{V}$ drink between the traditional endorsement and the real life condition is especially noteworthy. Overall, these results support $\mathrm{H} 2$.

\section{Mediation Tests (H3)}

Mediation analyses were conducted to identify whether SJP credibility mediates the relationships between endorsement conditions and consumer responses. We used PROCESS 
macro for SPSS (Hayes 2013). Table 2 reports the regression coefficients for the paths through the credibility mediator, for the direct effects of the endorsement conditions on the brand responses, and for the mean indirect effects. We used sequential coding to recode the multicategorical independent variable endorsement condition. With sequential codes, the relative direct and indirect effects can be interpreted as the effect of membership in one condition relative to the condition one step sequentially lower in the ordered system of control condition, then advertising endorsement, followed by product placement, and finally real-life condition. Similarly to Bergkvist, Hjamalverson, and Mägi (2016), the confidence interval for the indirect effect is the equivalent of the Sobel test (i.e. if zero is excluded from the confidence interval, then the total mediated effect of the independent variable on the dependent variable is statistically significant at the chosen level of 95\%). The analyses reveal a perfect mediating effect of SJP credibility for real-life condition relative to the product placement condition on brand attitudes (H3a is supported), purchase intentions (H3b is supported), willingness to pay (H3c is supported), and self-brand connection (H3d is supported): the mean indirect effects were significant, none of the confidence intervals included zero, and the c' paths were not significant. This significant mediation signals that the process underlying the real-life association is that this type of association generates a greater perceived credibility of the celebrity compared to product placement, and in turn this leads to more positive brand outcomes. The analyses with the other dummies reveal no mediating effect when contrasting control vs. advertising and advertising vs. product placement. We also conducted a mediation analysis using indicator coding with real-life association as the reference, and the results confirm that the mediation process is only significant when contrasting real-life association vs. product placement.

INSERT TABLE 2 ABOUT HERE 


\section{Discussion}

Overall, this experiment reveals that the many contexts and ways in which consumers witness celebrity-brand associations today have direct implications for how they perceive the celebrity but also for how they respond to the brand. Celebrity-brand associations that form within the realm of advertising or product placement generate weaker effects than celebritybrand associations that appear more genuine, because they emerge in the real world. Because the experiment relied on a real but previously unknown brand, the effects were striking: willingness to pay and try this new drink was highest when introduced as part of the normal world of Sarah Jessica Parker.

On the whole, the study reveals generally superior effects of the more natural real-life associations on consumers' responses to a previously unknown brand without eroding their perceptions of the celebrity associated with the brand: they like the brand more, feel more connected to it, are more willing to try it and even to pay more for it when they first encounter it with a celebrity in a natural, non-commercial setting. Neither traditional advertising nor product placement in a movie generated as positive a response to the brand as the natural association did. The study further reveals that the process underlying this favorable influence of real-life celebrity-brand associations is that, in those contexts, celebrities are perceived as more credible, and in turn this credibility drives positive brand responses. In contrast, more commercial forms of endorsements are detrimental to the credibility of a human brand and this is also reflected in reactions to a brand associated with the celebrity in commercial contexts.

\section{Limitations}

Notwithstanding these interesting results, the study is limited in several ways. First, the focus on a single celebrity and a single brand, while indicative of potentially larger 
phenomena, still limits the conclusion to this context and celebrity. Future studies should replicate the findings by testing the model across a larger range of celebrities, brands, and vary the degree to which brands and celebrities are viewed as 'fitting'. The experimental instructions were also provided without reference to a context / medium in which these photos may appear. Given the role of the media context in shaping the general meaning of a celebrity, future research could incorporate this additional dimension to the framework (McCracken 1989). Finally, the reliance on a single type of celebrity-brand association per condition maximized the experiment's internal validity but does not allow an assessment of the impact of multiple types of associations. Given the complexity and diversity of celebrity meanings and the increasing convergence of media, future research should identify the overall effects of exposure to different types of celebrity-brand associations (Hackley and Hackley 2015).

\section{Theoretical Implications}

The study provides new insights about the potentially negative impact of brand endorsements on consumers' perceptions of the celebrity itself. Celebrity credibility appears to erode more easily in a commercial context than in a natural one: merely associating Sarah Jessica Parker with a brand in a movie or a commercial yielded significantly lower perceptions of her credibility than in a natural, real life association. That human brands are fragile suggests more careful attention to their evolution in terms of brand management (Thomson 2006). Any and all associations with a brand, an event, or even other celebrities may alter consumers’ perceptions of credibility, attractiveness, and overall liking, confirming the need for a new paradigm of celebrity 'endorsement’ (Hackley and Hackley 2015).

These initial findings signal the need for further research, especially with regards to the seemingly more authentic, natural brand-celebrity associations, which are increasingly common in social media (Marwick 2011). As social media can also further amplify the degree 
to which fans connect with celebrities, these real-life brand associations are especially powerful (Click et al. 2013). However, given that some celebrity-brand associations in social media are negative (Colapinto and Benecchi 2014), it would be interesting to assess whether the degree to which consumers feel personally connected with a celebrity (Russell, Norman, and Heckler 2004) also leads to lesser criticism in social media.

Of course, there may be protective factors that preempt the erosion of celebrity credibility, for instance when consumers have strong parasocial relationships with the celebrity (Russell et al. 2004). For highly connected consumers, celebrities, in real life or through their recurring presence in TV series, evolve on a similar timescale to their audiences and this parallel increases the degree to which people expect that they do use real brands in their worlds, whether the real world, or the entertainment one in which viewers immerse themselves (Russell et al. 2004; Van Laer et al. 2014). It is possible that the credibility of celebrities associated with brands through product placement would erode less for consumers who are highly connected to their TV world. Future research can investigate these questions. Another consequence of the rise of social media is the changing definition of celebrity. Endorsers are not limited to the realms of cinema, television, music or sport anymore. Social media platforms and reality television have created their own celebrities. Among current top influencers are Vine star Logan Paul, YouTuber Tyler Oakley, or reality television personality Kylie Jenner.

\section{Marketing Implications}

Clearly, natural celebrity associations can be beneficial to brands and marketers have started to engage in this trend. The State of Influencer Marketing 2017 study (Linqia, 2016) reports that $86 \%$ of the surveyed marketers used influencer marketing in 2016, that influencer 
marketing program budgets are set to increase from an average of \$25K per program in 2016 to $\$ 50 \mathrm{~K}$ per program in 2017, and Facebook and Instagram are cited as twice more important than any other social media platform. Captiv8, an analytics platform that connects brands to social media “influencers”, reported that in 2016, more than 200,000 Instagram posts a month have been tagged with “\#ad”, “\#sp” or “\#sponsored” (The Economist, 17 ${ }^{\text {th }}$ October 2016). This number does not account for posts engaging in the same practice but not disclosing its sponsored nature. Native advertising, an increasingly popular practice, describes a spectrum of new online advertising forms that share a focus on minimizing disruption to a consumer's online experience by appearing in-stream (Campbell and Marks 2015). So native advertising can relate to any paid advertising that takes the specific form and appearance of editorial content from the publisher itself, when advertisers create or sponsor content intended to blend in with the editorial content (Carlson 2015). The advent of native advertising provides brands with a means to serve relevant and desired information to a broad, receptive audience. It also allows marketing managers to bypass ad skepticism and its usually associated defense mechanism, to generate a more positive message response. However, the practice is rather frowned upon as it is associated with subterfuge and trickery. Indeed, many critics view it as masking source attribution and deceiving consumers by making the source of the message ambiguous or secret.

From a human brand perspective, the study signals that celebrities ought to be cautious about their associations with brands. The study shows that celebrities' credibility can be affected by their involvement with brands and that even overall attitudes toward the celebrity can be negatively impacted by a single exposure to a celebrity endorsement.

\section{Policy Implications}

The finding that natural brand-celebrity connections are altogether more persuasive than the more commercial ones has direct policy implications. Indeed, the proliferation of 
brands in social media feeds faces strong criticism from consumer advocacy groups and public policy officials, who worry that audiences are unable to distinguish genuine brand appearances from paid-for endorsements (Matthes and Naderer 2016). The rise of native advertising, forms of advertising that disguise the official nature of the celebrity-brand association, has generated much controversy about the potential deception involved with such seemingly natural images that in fact reflect hidden endorsements, and some have advocated the use of disclosure in any endorsement that appears natural but that may in fact be of a commercial, paid-for nature (Advertising Standard Authority 2015; Federal Trade Commission 2015). For policymakers, any brand-celebrity association that may lead consumers "to believe (the association) reflects the opinions, beliefs, findings, or experiences of a party other than the sponsoring advertiser, even if the views expressed by that party are identical to those of the sponsoring advertiser” is treated as an endorsement and should follow the same rules as 'commercial endorsements’ (Federal Trade Commission 2015). Yet, as this paper shows, different forms of endorsement can have quite different effects.

\section{Conclusion}

To our knowledge, this is the first investigation that directly compares celebrity endorsement advertising to product placement and natural brand-celebrity associations. Advertising researchers have only recently begun to consider how marketing messages conveyed in different forms may interact to influence attention and persuasion to brand communications (e.g. commercials vs. product placements, Schweidel, Foutz, and Tanner 2014). This research, using a celebrity differently associated with a brand, signals that new insights can emerge from comparing the impact of different types of messages, especially as the array of marketing message formats keeps enlarging. 


\section{References}

Advertising Standard Authority. 2015. https://www.asa.org.uk/News-resources/MediaCentre/2015/New-vlogging-advertising-guidance.aspx\#.V7SvUZMrKRs (accessed August 18, 2016).

Amos, C., G. Holmes, and D. Strutton. 2008. Exploring the relationship between celebrity endorser effects and advertising effectiveness. A quantitative synthesis of effect size. International Journal of Advertising 27, no. 2: 209-234.

Baker, M. J., and G. A. Churchill, Jr. 1977. The impact of physically attractive models on advertising evaluations. Journal of Marketing Research 14, November: 538-555.

Balasubramanian, S. K. 1994. Beyond advertising and publicity: Hybrid messages and public policy issues. Journal of Advertising 23, December: 29-46.

Belch, G. E., and M. A. Belch. 2013. A content analysis study of the use of celebrity endorsers in magazine advertising. International Journal of Advertising 32, no. 3: 369389.

Bergkvist, L., and Zhou, K. Q. 2016. Celebrity endorsements: A literature review and research agenda. International Journal of Advertising 35, no. 4: 642-663.

Bergkvist, L., H. Hjalmarson, and A. W. Mägi. 2016. A new model of how celebrity endorsements work: Attitude toward the endorsement as a mediator of celebrity source and endorsement effects. International Journal of Advertising 35, no. 2: 171-184.

Bullen, E. 2009. Inside story: Product placement and adolescent consumer identity in young adult fiction. Media, Culture and Society 31, no. 3: 497-507.

Bush, A. J., C. A. Martin, and V. D. Bush. 2004. Sports celebrity influence on the behavioral intentions of generation Y. Journal of Advertising Research 44, no. 1: 108-118. 
Campbell, M. C., and A. Kirmani. 2000. Consumers' use of persuasion knowledge: The effects of accessibility and cognitive capacity on perceptions of an influence agent. Journal of Consumer Research 27, June: 69-83.

Campbell, C., and L. J. Marks. 2015. Good native advertising isn’t a secret. Business Horizons 58, no. 6: 599-606.

Carlson, M. 2015. When news sites go native: Redefining the advertising-editorial divide in response to native advertising. Journalism 16, no. 7: 849-865.

Chaiken, S. 1979. Communicator physical attractiveness and persuasion. Journal of Personality and Social Psychology 37, no. 8: 1387-1397.

Choi, S. M., W. N. Lee, and H. J. Kim. 2005. Lessons from the rich and famous: A crosscultural comparison of celebrity endorsement in advertising. Journal of Advertising 34, no. 2: 85-98.

Choi, S. M., and N. J. Rifon. 2012. It is a match: The impact of congruence between celebrity image and consumer ideal self on endorsement effectiveness. Psychology \& Marketing 29, no. 9: 639-650.

Click, M. A., H. Lee, and H. W. Holladay. 2013. Making monsters: Lady Gaga, fan identification, and social media. Popular Music and Society 36, no. 3: 360-379.

Colapinto, C., E. Benecchi. 2014. The presentation of celebrity personas in everyday twittering: Managing online reputations throughout a communication crisis. Media, Culture \& Society 36, no. 2: 219-233.

Dahlén, M. 2005. The medium as contextual cue: Effects of creative media choice. Journal of Advertising 34, no. 3: 89-98.

Escalas, J. E. 2004. Narrative processing: Building consumer connections to brands, Journal of Consumer Psychology 14, no. 1: 168-179.

Eisend, M., and T. Langner. 2010. Immediate and delayed advertising effects of celebrity 
endorsers' attractiveness and expertise. International Journal of Advertising 29, no. 4: 527-546.

Erdogan, B. Z. 1999. Celebrity endorsement: A literature review. Journal of Marketing Management 15, no. 4: 291-314.

Federal Trade Commission. 2015. https://www.ftc.gov/sites/default/files/attachments/press-releases/ftc-publishes-finalguides-governing-endorsements-testimonials/091005revisedendorsementguides.pdf (accessed August 18, 2016).

Festinger, L. 1954. A theory of social comparison processes. Human Relations 7, no. 2: 117140.

Friestad, M., and P. Wright. 1994. The persuasion knowledge model: How people cope with persuasion attempts. Journal of Consumer Research 21, no. 1: 1-31.

Gill, J. D., S. Grossbart, and R. N. Laczniak. 1988. Influence of involvement, commitment and familiarity on brand beliefs and attitudes of viewers exposed to alternative ad claim strategies. Journal of Advertising 17, no. 2: 33-43

Greenwald, A. G. 1968. Cognitive learning, cognitive responses to persuasion and attitude change. In Psychological Foundations of Attitudes, eds. A. G. Greenwald, T. C. Brock, T. M. Ostrom, 147-170. New York: Academic Press.

Greenwald, A. G., and Leavitt, C. 1984. Audience involvement in advertising: Four levels. Journal of Consumer Research 11, no. 1: 581-592.

Hackley, C., and R. A. Hackley. 2016. The iconicity of celebrity and the spiritual impulse. Consumption Markets \& Culture, 19, no. 3: 269-274.

Hackley, C., and R. A. Hackley. 2015. Marketing and the cultural production of celebrity in the era of media convergence. Journal of Marketing Management, 31, no. 5-6: 461477. 
Halonen-Knight, E., and L. Hurmerinta. 2010. Who endorses whom? Meanings transfer in celebrity endorsement. Journal of Product \& Brand Management 19, no. 6: 452-460.

Heath, T. B., M. S. McCarthy, and D. L. Mothersbaugh, D. L. 1994. Spokesperson fame and vividness effects in the context of issue-relevant thinking: The moderating role of competitive setting. Journal of Consumer Research, 20, March: 520-34.

Heine, C. (2016). Selena Gomez's Social Media Posts Are Evidently Worth \$550,000 Apiece. Adweek, July 19. http://www.adweek.com/news/technology/selena-gomezs-socialmedia-posts-are-evidently-worth-550000-apiece-172552 (accessed August 19, 2016).

Hirschman, E. C., and C. J. Thompson. 1997. Why media matter: Toward a richer understanding of consumers' relationships with advertising and mass media. Journal of Advertising 26, no. 1: 43-60.

Huckfeldt, R. R., and Sprague, J. 1995. Citizens, Politics And Social Communication: Information And Influence In An Election Campaign. Cambridge, UK: Cambridge University Press.

Hovland, C., I. Janis, and H. Kelley. 1953. Communications and Persuasion. New Haven: Yale University Press.

Hung, K. 2014. Why celebrity sells: A dual entertainment path model of brand endorsement. Journal of Advertising 43, no. 2: 155-166.

Jin, S. A. A., and J. Phua. 2014. Following celebrities' tweets about brands: The impact of twitter-based electronic word-of-mouth on consumers’ source credibility perception, buying intention, and social identification with celebrities. Journal of Advertising 43, no. 2: 181-195.

Jussim, L., and Osgood, D. W. 1989. Influence and similarity among friends: An integrative model applied to incarcerated adolescents. Social Psychology Quarterly: 98-112.

Kahle, L. R., and P. Homer. 1985. Physical attractiveness of the celebrity endorser: A 
social adaptation perspective. Journal of Consumer Research 11, no. 4: 954-61.

Kamen, J. M., A. C. Azhari, and J. R. Kragh. 1975. What a spokesperson does for a sponsor. Journal of Advertising Research 16, no. 2: 17-24.

Kamins, M. A., M. J. Brand, S. A. Hoeke, J. C. Moe. 1989. Two-sided versus onesided celebrity endorsements: The impact of advertising effectiveness and credibility. Journal of Advertising 18, no. 2: 4-10.

Le Gall-Ely, M. 2009. Definition, measurement and determinants of the consumer's willingness to pay: A critical synthesis and avenues for further research. Recherche et Applications en Marketing (English Edition) 24: 91-112.

Linqia (2016). The State of Influencer Marketing 2017: A look into how brands and agencies view the future of influencer marketing.

Marwick, A. 2011. To see and be seen: Celebrity practice on Twitter. Convergence: The International Journal of Research Into New Media Technologies 17, no. 2: 139-158.

Matthes, J. and B. Naderer. 2016. Product placement disclosures: Exploring the moderating effect of placement frequency on brand responses via persuasion knowledge. International Journal of Advertising 35, no. 2: 185-199.

McCracken, G. 1989. Who is the celebrity endorser? Cultural foundations of the endorsement process. Journal of Consumer Research 16: 310-21.

Miller, K. M., R Hofstetter, H Krohmer, and Z. J. Zhang. 2011. How should consumers' willingness to pay be measured? An empirical comparison of state-of-the-art approaches. Journal of Marketing Research 48, no. 1: 172-184.

Millward Brown Perspectives. 2013. http://www.millwardbrown.com/docs/defaultsource/insight-documents/published-books/MillwardBrown_Perspectives_v6.pdf (accessed August 18, 2016). 
Misra, S., and Beatty, S. E. 1990. Celebrity spokesperson and brand congruence: An assessment of recall and affect. Journal of Business Research 21, no. 2: 159-173.

Moore, D. J., J. C. Mowen, and R. Reardon. 1994. Multiple sources in advertising appeals: When product endorsers are paid by the advertising sponsor. Journal of the Academy of Marketing Science 22, no. 3: 234-243.

Ohanian, R. 1990. Construction and validation of a scale to measure celebrity endorsers' perceived expertise, trustworthiness, and attractiveness. Journal of Advertising 19, no. 3 : $39-52$.

Ohanian, R. 1991. The impact of celebrity spokespersons’ perceived image on consumers’ intention to purchase. Journal of Advertising Research 31, February/March: 46-54. PQ Media. 2016. PQ Media Global Product Placement Spending Forecast 2015-2019. http://www.pqmedia.com/gbemf-2015-2019.html (accessed August 18, 2016).

Russell, C. A. (2002). Investigating the effectiveness of product placements in television shows: the role of modality and plot connection congruence on brand memory and attitude. Journal of Consumer Research 29, no. 3: 306-318.

Russell, C. A., A. T. Norman, S. E. Heckler. 2004. The consumption of television programming: Development and validation of the connectedness scale. Journal of Consumer Research 31, no. 1: 150-61.

Russell, C. A. and D. W. Russell. 2010. Guilty by stereotypic association: Country animosity and brand prejudice and discrimination. Marketing Letters 21, no. 4: 413-425.

Russell, C. A., and B. Stern. 2006. Consumers, characters, and products: A balance model of sitcom product placement effects. Journal of Advertising 35, no. 1: 7-18.

Schweidel, D. A., N. Z. Foutz, and R. J. Tanner. 2014. Synergy or Interference: The Effect of Product Placement on Commercial Break Audience Decline. Marketing Science 33, no. 6: 763-780, 883-884. 
Silvera, D. H., and A. Benedikte. 2004. Factors predicting the effectiveness of celebrity endorsement advertisements. European Journal of Marketing 38, no. 11/12: 1509 1526.

Stever, G. S., and K. Lawson. 2013. Twitter as a way for celebrities to communicate with fans: Implications for the study of parasocial interaction. North American Journal of Psychology 15: 339-354.

The Economist (17 $7^{\text {th }}$ October 2016). Celebrities' endorsement earnings on social media. http://www.economist.com/blogs/graphicdetail/2016/10/daily-chart-9 (accessed 20/01/2017)

Thomson, M. 2006. Human brands: Investigating antecedents to consumers’ strong attachments to celebrities. Journal of Marketing 70, no. 3: 104-119.

Till, B. D., and T. A. Shimp. 1998. Endorsers in advertising: The case of negative celebrity information. Journal of advertising 27, no. 1: 67-82.

Tripp, C., T. D. Jensen, and L. Carlson. 1994. The effects of multiple product endorsements by celebrities on consumers' attitudes and intentions. Journal of Consumer Research 20, no. 4: 535-547.

Van Laer, T., K. De Ruyter, L. M. Visconti, and M. Wetzels. 2014. The extended transportation-imagery model: A meta-analysis of the antecedents and consequences of consumers’ narrative transportation. Journal of Consumer Research 40, no. 5: 797-817.

Wright, P. L. 1973. The cognitive processes mediating acceptance of advertising. Journal of Marketing Research 10, no. 1: 53-62. 
Table 1 - Means (Standard Deviations) for all Variables by Experimental Condition

\begin{tabular}{|c|c|c|c|c|c|}
\hline & & $\begin{array}{l}\text { Control (no } \\
\text { celebrity-brand } \\
\text { connection) }\end{array}$ & Advertising & $\begin{array}{c}\text { Product } \\
\text { Placement }\end{array}$ & $\begin{array}{l}\text { Real life } \\
\text { (natural) }\end{array}$ \\
\hline \multirow[t]{4}{*}{ Brand Measures } & Brand Attitude & $3.15^{\mathrm{a}}(.91)$ & $3.63^{\mathrm{b}}(.92)$ & $3.34^{\mathrm{ab}}(.90)$ & $3.80^{\mathrm{b}}(.95)$ \\
\hline & $\begin{array}{l}\text { Purchase } \\
\text { intention }\end{array}$ & $3.05^{\mathrm{a}}(.97)$ & $3.36^{\mathrm{ab}}(1.15)$ & $3.42^{\mathrm{ab}}(1.06)$ & $3.87^{\mathrm{b}}(1.29)$ \\
\hline & $\begin{array}{l}\text { Willingness to } \\
\text { Pay (in \$) }\end{array}$ & $\$ 1.34^{\mathrm{a}}(.83)$ & $\$ 1.41^{\mathrm{a}}(.86)$ & $\$ 1.65^{\mathrm{ab}}(.86)$ & $\$ 1.91^{\mathrm{b}}(.95)$ \\
\hline & $\begin{array}{l}\text { Brand-self } \\
\text { connection }\end{array}$ & $2.64^{\mathrm{a}}(.86)$ & $2.80^{\mathrm{ab}}(.88)$ & $2.78^{\mathrm{ab}}(.88)$ & $3.24^{\mathrm{b}}(.1 .18)$ \\
\hline \multirow[t]{5}{*}{$\begin{array}{l}\text { Celebrity } \\
\text { Measures }\end{array}$} & $\begin{array}{l}\text { Overall } \\
\text { credibility }\end{array}$ & $3.88^{\mathrm{ab}}(.82)$ & $3.84^{\mathrm{ab}}(.99)$ & $3.61^{\mathrm{a}}(.99)$ & $4.27^{\mathrm{b}}(.95)$ \\
\hline & Trustworthiness & $3.55^{\mathrm{ab}}(.81)$ & $3.85^{\mathrm{ab}}(1.04)$ & $3.47^{\mathrm{a}}(.98)$ & $4.01^{\mathrm{b}}(1.01)$ \\
\hline & Attractiveness & $4.11^{\mathrm{abc}}(1.14)$ & $3.87^{\mathrm{ac}}(1.21)$ & $3.66^{\mathrm{ac}}(1.27)$ & $4.53^{b}(1.22)$ \\
\hline & Expertise & $3.97^{\mathrm{ab}}(1.01)$ & $3.81^{\mathrm{ab}}(1.02)$ & $3.70^{\mathrm{a}}(1.02)$ & $4.28^{\mathrm{b}}(.97)$ \\
\hline & $\begin{array}{l}\text { Attitude toward } \\
\text { the Celebrity }\end{array}$ & $3.59^{\mathrm{a}}(1.09)$ & $3.52^{\mathrm{a}}(1.17)$ & $3.31^{\mathrm{a}}(1.22)$ & $4.04^{\mathrm{b}}(1.24)$ \\
\hline $\begin{array}{l}\text { Product category } \\
\text { Involvement }\end{array}$ & & 2.59 (1.33) & $2.54(1.13)$ & $2.48(1.31)$ & 2.64 (1.08) \\
\hline
\end{tabular}

a, b, c Different superscript letters within a row indicate significant differences at $p<.05$ 
Table 2 - Results from mediation analyses for brand responses through celebrity credibility

\begin{tabular}{|c|c|c|c|c|c|c|}
\hline $\begin{array}{c}\text { Independent } \\
\text { variable }\end{array}$ & a path & $b$ path & $c$ path & $c^{\prime}$ path & $\begin{array}{c}\text { Mean } \\
\text { indirect } \\
\text { effect }(a x \\
b)\end{array}$ & $95 \% \mathrm{CI}$ \\
\hline \multicolumn{7}{|c|}{ Dependent variable: brand attitudes; Mediator: SJP credibility } \\
\hline $\begin{array}{c}\text { D1 } \\
\text { (control vs. ad) }\end{array}$ & -0.03 & $0.38 * * *$ & $0.47 *$ & $0.49 *$ & -0.01 & $\mathrm{~L}=-0.17 ; \mathrm{U}=0.16$ \\
\hline $\begin{array}{c}\text { D2 } \\
\text { (ad vs. PP) }\end{array}$ & -0.24 & $0.38 * * *$ & -0.29 & -0.20 & -0.09 & $\mathrm{~L}=-0.30 ; \mathrm{U}=0.08$ \\
\hline $\begin{array}{c}\text { D3 } \\
\text { (PP vs. real life) }\end{array}$ & $0.67 * *$ & $0.38 * * *$ & $0.49 *$ & 0.23 & 0.26 & $\mathrm{~L}=0.07 ; \mathrm{U}=0.53$ \\
\hline
\end{tabular}

Dependent variable: purchase intentions; Mediator: SJP credibility

\begin{tabular}{|c|c|c|c|c|c|c|}
\hline $\begin{array}{c}\text { D1 } \\
\text { (control vs. ad) }\end{array}$ & -0.03 & $0.38 * * *$ & 0.31 & 0.32 & -0.01 & $\mathrm{~L}=-0.19 ; \mathrm{U}=0.15$ \\
\hline $\begin{array}{c}\text { D2 } \\
\text { (ad vs. PP) }\end{array}$ & -0.24 & $0.38 * * *$ & 0.07 & 0.16 & -0.09 & $\mathrm{~L}=-0.31 ; \mathrm{U}=0.07$ \\
\hline $\begin{array}{c}\text { D3 } \\
\text { (PP vs. real life) }\end{array}$ & $0.67 * *$ & $0.38 * * *$ & 0.37 & 0.12 & 0.25 & $\mathrm{~L}=0.07 ; \mathrm{U}=0.53$ \\
\hline \multicolumn{7}{|c|}{ Dependent variable: willingness to pay; Mediator: SJP credibility } \\
\hline $\begin{array}{c}\text { D1 } \\
\text { (control vs. ad) }\end{array}$ & -0.03 & $4.26^{*}$ & 1.41 & 1.55 & -0.14 & $\mathrm{~L}=-2.63 ; \mathrm{U}=1.66$ \\
\hline $\begin{array}{c}\text { D2 } \\
\text { (ad vs. PP) }\end{array}$ & -0.24 & $4.26^{*}$ & 4.80 & 5.80 & -1.00 & $L=-4.48 ; U=0.71$ \\
\hline $\begin{array}{c}\text { D3 } \\
\text { (PP vs. real life) }\end{array}$ & $0.67 * *$ & $4.26 *$ & 4.90 & 2.06 & 2.84 & $\mathrm{~L}=0.23 ; \mathrm{U}=7.53$ \\
\hline \multicolumn{7}{|c|}{ Dependent variable: brand-self connection; Mediator: SJP credibility } \\
\hline $\begin{array}{c}\text { D1 } \\
\text { (control vs. ad) }\end{array}$ & -0.03 & $0.35 * * *$ & 0.16 & 0.17 & -0.01 & $\mathrm{~L}=-0.15 ; \mathrm{U}=0.15$ \\
\hline $\begin{array}{c}\text { D2 } \\
\text { (ad vs. PP) }\end{array}$ & -0.24 & $0.35 * * *$ & -0.02 & 0.06 & -0.08 & $\mathrm{~L}=-0.30 ; \mathrm{U}=0.07$ \\
\hline $\begin{array}{c}\text { D3 } \\
\text { (PP vs. real life) }\end{array}$ & $0.67 * *$ & $0.35 * * *$ & 0.44 & 0.21 & 0.24 & $L=0.07 ; U=0.49$ \\
\hline
\end{tabular}


APPENDIX 1 - Structure of stimuli for each celebrity-brand association condition

\section{CONTROL CONDITION}

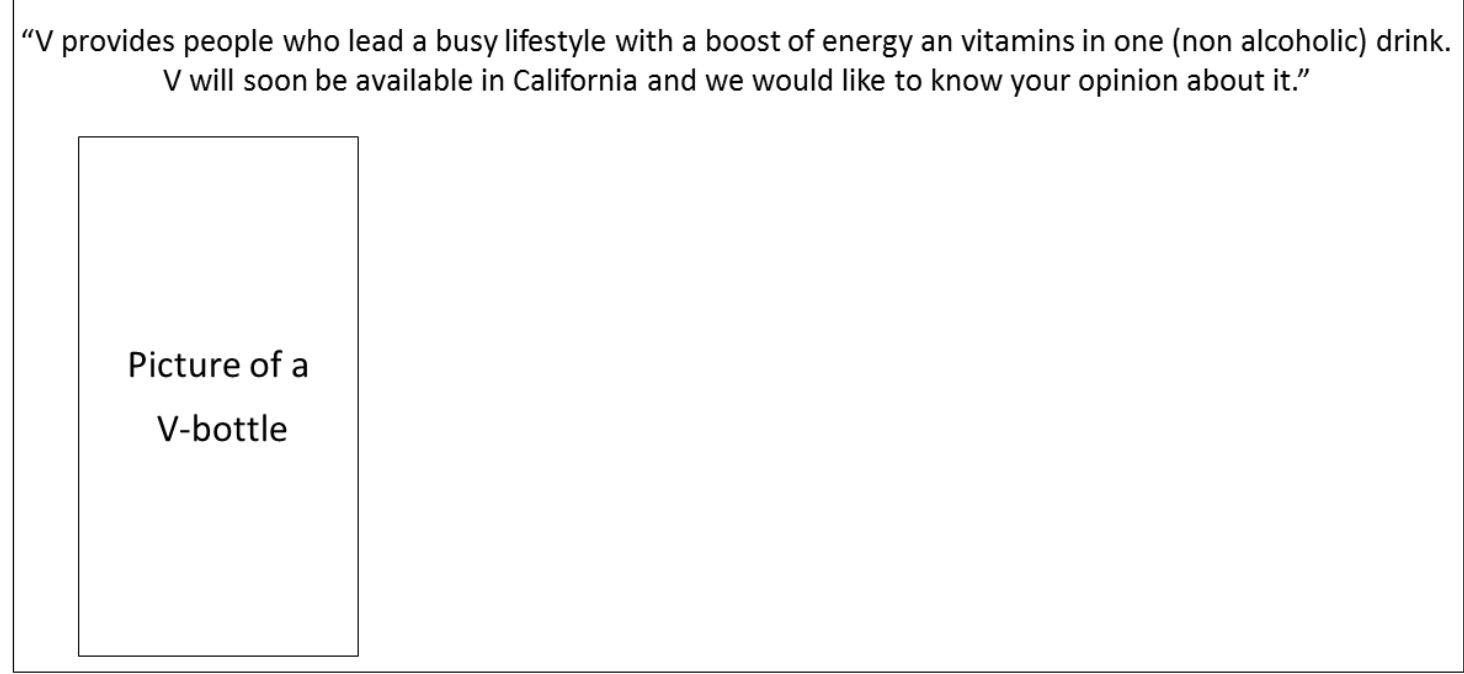

\section{ADVERTISING ENDORSEMENT CONDITION}

"As you know, celebrities such as Sarah Jessica Parker often endorse products in advertising. The following photos are from a forthcoming commercial for a new energy drink called "V". The commercial will show Sarah Jessica Parker in the streets of New York. Please take a few minutes to observe them."

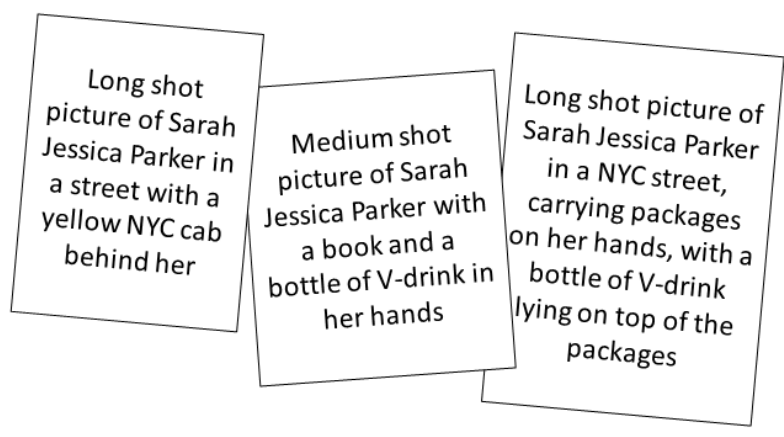




\section{PRODUCT PLACEMENT CONDITION}

"As you know, celebrities such as Sarah Jessica Parker are often seen with product placements in movies. The following photos are of Sarah Jessica Parker's new movie "Sex and the City: the Movie" that will be released at the end of May and that was shot mainly in New York. Please take a few minutes to observe them."

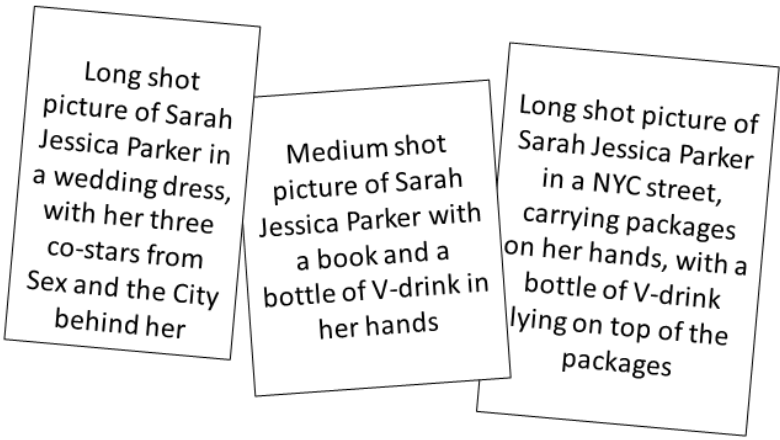

\section{REAL LIFE ASSOCIATION}

"As you know, celebrities such as Sarah Jessica Parker are often caught on camera during their day-to-day life. The following photos of Sarah Jessica Parker were taken by passer-bys who spotted her on the streets of New York. Please take a few minutes to observe them."

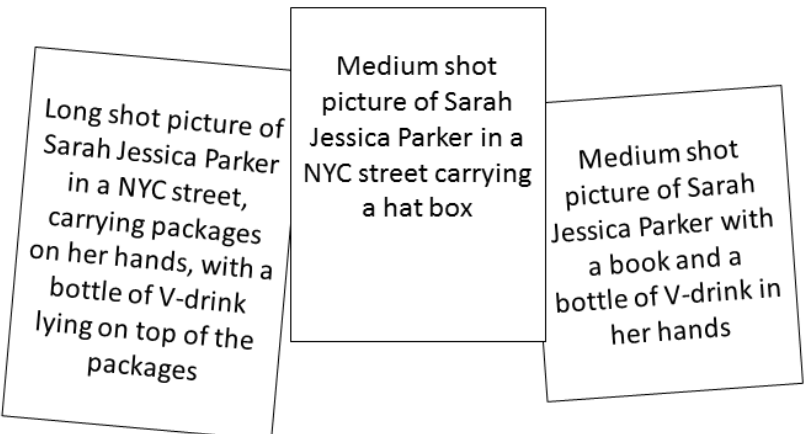

